\title{
Persepsi Generasi Milenial dalam Memilih Produk Bersertifikat Halal di Jakarta
}

\section{Tati Handayani}

Universitas Pembangunan Nasional Veteran Jakarta

tati.handayani@upnvj.ac.id

\author{
Anggi Angga Resti \\ Universitas Pembangunan Nasional Veteran Jakarta \\ anggianggaresti@upnvj.ac.id
}

\begin{abstract}
Abstrak Pertumbuhan ekonomi syariah merupakan salah satu indikator pertumbuhan ekonomi suatu negara, tidak terkecuali bagi pertumbuhan industri halal. Saat ini pandemi berampak buruk terhadap perekonomian, namun ini justru menarik banyak industri halal untuk berinovasi dan memperbaiki mutu produknya. Penelitian ini bertujuan untuk mengetahui apakah variabel-variabel persepsi kualitas produk, nilai produk dan gaya hidup mempengaruhi minat produk bersertifikat halal. Metode penelitian menggunakan metode deskriptif dengan pendekatan kualitatif. Data yang digunakan adalah data primer yang diperoleh melalui penyebaran kuisioner kepada 232 responden, dengan kriteria sampel generasi milenial berusia di bawah 30 tahun berdomisili di wilayah DKI Jakarta. Hasil penelitian menunjukkan: secara parsial hanya variabel persepsi kualitas produk dan gaya hidup yang memiliki pengaruh secara positif dan signifikan terhadap sertifikat halal. Sedangkan hipotesis tiga tidak terbukti karena variabel persepsi nilai produk tidak menunjukkan pengaruh terhadap sertifikat halal. Secara simultan variabel persepsi kualitas produk, persepsi nilai produk dan gaya hidup memiliki pengaruh signifikan terhadap sertifikat halal.
\end{abstract}

Kata Kunci Gaya Hidup, Kualitas Produk Halal, Nilai Produk dan Sertifikat Halal

\section{PENDAHULUAN}

Pesatnya perkembangan bisnis di Indonesia baik dari skala mikro, skala kecil, skala menengah sampai dengan skala besar. Menyoroti perkembangan bisnis di negara ini tidak lepas dari pesatnya pertumbuhan di sektor kuliner yang kian hari kian menjamur. Kebutuhan masyarakat dalam bidang sandang dari ketiga macam kebutuhan pokok memang merupakan hal utama, makanan dan minuman yang dikonsumsi merupakan sumber energi untuk melakukan aktivitas kegiatan sehari- hari. Dalam kebudayaan agama Islam masyarakat memilih makanan yang sehat dan aman dikonsumsi salah satu faktor penentunya adalah adanya logo halal dalam produk tersebut. Logo halal dianggap penting dan dianggap mampu menjamin komposisi produk tersebut tidak terdapat komponen- komponen yang membahayakan atau haram untuk dimakan (Chairani, 2021). Logo halal dapat membantu konsumen dalam memilih produk dan memberikan informasi 
mengenai isi kandungan suatu produk. Sekarang ini banyak para produsen yang sudah mendaftarkan produknya untuk memperoleh sertifikasi halal di Majelis Ulama Indonesia. Mereka sadar bahwa dengan mendaftarkan produknya tersebut dapat memberikan keuntungan tersendiri berupa daya tarik produk tersebut meningkat dimata konsumen serta citra produk tersebut juga menjadi lebih bagus dimata konsumen (Yuliyanto, 2020). Sejalan dengan program pemerintah dengan di turunkannya UU No. 33 tahun 2014 tentang jaminan dan kewajiban semua produk memiliki sertifikat halal. Kebijakan disambut baik oleh para produsen UMKM di Indonesia dengan jumlah UMKM yang bersertifikat halal mencapai 59.951 usaha. Setiap tahunnya mengalami peningkatan yang signifikan, hal tersebut karena ada dukungan pemerintah khususnya kementrian koperasi dan UMKM yang membuat program menggratiskan biaya sertifikasi halal bagi para pelaku usaha berskala mikro, kecil dan menengah pada tahun 2020 (HumasKemenkop, 2020).

Persepsi konsumen mengenai kualitas produk tentu saja berbeda- beda, konsumen melihat citra suatu produk bisa saja dari pengalaman mereka membeli produk tersebut ataupun rekomendasi dari lingkungan sekitar tentang manfaat yang diberikan dari suatu produk. Akan tetapi keberadaan sertifikasi halal khususnya bagi masyarakat muslim memberikan suatu kepercayaan tersendiri untuk membeli produk tersebut. (Chairani, 2019). Persepsi nilai mengenai produk yang bersertifikasi halal di mata konsumen. Sedikit banyaknya banyak dari konsumen yang sadar akan keberadaan logo halal pada label suatu produk. Mereka yang sadar dan peduli akan keberadaan logo halal tersebut merupakan konsumen yang mengerti maksud dan tujuan mengapa logo tersebut berada pada produk tersebut. Kadang kala pada suatu produk yang mengandung unsur protein hewani atau daging, banyak dari konsumen bertanya- tanya apakah kandungan dari protein hewani tersebut dan apa dampaknya untuk dimakan. Maka dari itu disinilah kegunaan dari logo halal berada pada kemasan suatu produk atau terpampang pada merek- merek restoran pada pusat-pusat perbelanjaan. Logo halal tersebut memberikan persepsi nilai sendiri dimata konsumen yang tidak langsung memberikan keuntungan sendiri dipihak produsen. Pemilihan objek yang dipilih adalah generasi milenial yang berada di kota Jakarta. Alasan pemilihan kota Jakarta sebagai objek penelitian adalah kota dengan tingkat konsumsi produk kedua di Indonesia setelah Bekasi akan tetapi wilayah kota Madya kota Jakarta Utara, Jakarta Selatan dan Jakarta Barat merupakan wilayah dengan tingkat konsumsi produk tertinggi di Indonesia mengalahkan kota Bekasi meurut data BPS yang dilansir Kompas.com (Ulya, 2020). Pemilihan generasi milenial sebagai objek adalah karena generasi milenial dianggap salah satu generasi yang paling bersifat konsumtif dalam membelanjakan uangnya untuk membeli produk yang mereka inginkan menurut (Kompasiana, 2020).

\section{LANDASAN TEORI}

\section{A. 1. Sertifikasi Halal}

Sertifikasi halal merupakan suatu pengakuan dari kehalalan produk yang dikeluarkan Badan penyelenggara jaminan produk halal berdasarkan fatwa halal yang telah tertulis dan dikeluarkan oleh MUI. Kemudian pendapat lain terkait sertifikasi halal merupakan suatu proses dari penyertaan label yang dirancang dalam melindungi pelanggan dari informasi yang akurat terkait jumlah kualitas serta isi produk (Zulham, S.Hi, 2013). Sertifikat Halal adalah suatu fatwa tertulis dari Majelis Ulama Indonesia (MUI) yang menyatakan kehalalan suatu produk sesuai dengan syari'at Islam. Sertifikat Halal ini merupakan syarat untuk mendapatkan ijin pencantuman LABEL HALAL pada kemasan 
produk dari instansi pemerintah yang berwenang (Maiti \& Bidinger, 1981). Indikator sertifikasi halal: (Setyaningsih \& Marwansyah, 2019)

1. Terdapat logo hala dalam kemasan produk makanan adalah hal yang terpenting

2. Dapat membedakan mana logo halal otentik dari MUI san logo halla yang tidak otentik

3. Produk bersertifikat halal berkualitas

4. Produk berlogo halal telah melalui serangkaian proses uji halal yang ketat

5. Tidak ragu untuk mengkomsumsi makanna berlogo halal

\section{Persepsi Kualitas Produk}

Persepsi kualitas produk yang di artikan menjadi suatu persepsi pelanggan terhadap keseluruhan dari keunggulan atau kualitas produk yang sesuai dengan harapan pelanggan (Darmadi Durianto, 2001). Selanjutnya persepsi kualitas produk juga memiliki pengertian sebagai salah satu kunci dari dimensi ekuitas merek. Yang dimana memiliki atribut yang sangat penting untuk bisa di aplikasikan didalam berbagai hal yaitu: kualitas actual, kualitas isi produk, kualitas proses manufaktur. Definisi lain dari persepsi kualitas produk merupakan persepsi dari konsumen terhadap kualitas produk yang sifatnya subjektif serta bukan suatu kualitas dari sesungguhnya dari produk (Rifyal Dahlawy Chalil, 2020). Menurut pendapat lain (Harjati \& Sabu, 2014) dalam buku Kotler Keller indikator persepsi kualitas produk memiliki indikator antara lain:

1. Mutu kinerja (performance), merupakan hal pokok yang berkaitan dengan fungsi utama dari suatu produk.

2. Keandalan (reliability), merupakan standart suatu produk layak di konsumsi atau di gunakan, tidak rusak dalam suatu periode tertentu.

3. Keunikan atau istimewa (feature), produk memiliki ciri khas untuk ditawarkan dengan berbagai unsur pembeda dari pesaing, misalnya desain produk yang futuristic melengkapi kegunaan utama sebuah produk.

4. Daya tahan atau keawetan (durability), keawetan menunjukkan masa pakai suatu produk, yaitu ukuran usia dan performa yang tidak menurut dalam kurun waktu tertentu.

5. Mutu kesesuaian (conformance quality), produk telah melalui standart quality control yang baik sehingga produk yang di keluarkan memiliki kualitas bagus.

\section{Persepsi Nilai Produk}

Persepsi nilai produk adalah menyatakan nilai produk sebagai pengkajian secara menyeluruh manfaat dari suatu produk, didasarkan persepsi pelanggan atas apa yang telah diterima oleh pelanggan dan yang telah diberikan oleh produk tersebut (Rangkuti, 2002). Sedangkan menurut pengertian lain mengemukakan bahwa konsep nilai produk mempunyai hubungan yang erat dengan kepuasan konsumen, dimana nilai-nilai yang dirasakan saat mengkonsumsi produk akan membentuk kepuasan konsumen, dan kepuasan konsumen ini berpengaruh terhadap loyalitas konsumen (Yuriansyah, 2013).

Indikator persepsi nilai yaitu Pengenalan perusahaan, merupakan bagaimana pandangan suatu perusahaan dimata konsumen secara spontan tanpa di arahkan murni berdasarkan pengetahuan dan pengalaman dari konsumen tersebut. Kedua persepsi nilai perusahaan terhadap pesaing, yaitu bagaimana posisi perusahaan di dalam bidang bisnis tersebut sebagai lider, follower ataupun chalanger dimata konsumennya. Ketiga yaitu pengenalan produk atau Jasa merupakan bentuk strategi perusahaan untuk membangun ingatan konsumen tentang citra perusahaan itu sendiri, perusahaan membuat konsumen 
senyaman mungkin untuk menumbuhkan sifat loyal kepada perusahaan. Terakhir Nilai produk yaitu seberapa besar perbandingan nilai guna atau manfaat yang diberikan suatu produk terhadap biaya yang dikeluarkan konsumen untuk memperoleh produk tersebut (Soegoto, 2013).

\section{Gaya Hidup}

Persepsi nilai produk adalah menyatakan nilai produk sebagai pengkajian secara menyeluruh manfaat dari suatu produk, didasarkan persepsi pelanggan atas apa yang telah diterima oleh pelanggan dan yang telah diberikan oleh produk tersebut (Rangkuti, 2002). Sedangkan menurut pengertian lain mengemukakan bahwa konsep nilai produk mempunyai hubungan yang erat dengan kepuasan konsumen, dimana nilai-nilai yang dirasakan saat mengkonsumsi produk akan membentuk kepuasan konsumen, dan kepuasan konsumen ini berpengaruh terhadap loyalitas konsumen (Yuriansyah, 2013).

Gaya hidup seseorang biasanya tidak permanen dan cepat berubah, indikator yang menjelaskan gaya hidup sering kali digambarkan dengan kegiatan, minat, dan opini (Activities, Interest, and Opinion/AIO) dari seseorang (Sumarwan, 2011). Hal tersebut juga sejalan dengan Plumer dan Assael dalam (Setiadi, 2019) yang menekankan tiga hal penting yang dapat dijadikan pertimbangan dalam mengevaluasi gaya hidup konsumen sehari-hari, yaitu: apa yang mereka rasakan, bagaimana sikap dan opini mereka terhadap berbagai fakta kehidupan.Gaya hidup akan berkembang pada masing-masing dimensi (aktivitas, interes, opini/AIO) seperti telah diidentifikasi oleh Plummer dalam Assael (1997) dalam (Setiadi, 2019) yang terjadi dalam Tabel 1.

Tabel 1. Inventarisasi Gaya Hidup

\begin{tabular}{|c|c|c|}
\hline Aktivitas & Interest & Opini \\
\hline Bekerja & Keluarga & Diri mereka sendiri \\
\hline Hobi & Rumah & Masalah-masalah sosial \\
\hline Peristiwa sosial & Pekerjaan & Politik \\
\hline Liburan & Komunitas & Bisnis \\
\hline Hiburan & Rekreasi & Ekonomi \\
\hline Anggota Klub & Pakaian & Pendidikan \\
\hline Komunitas & Makanan & Produk \\
\hline Belanja & Media & Masa depan \\
\hline Olahraga & Prestasi & Budaya \\
\hline
\end{tabular}

\section{State Of The Art}

Perkembangan isu tentang halal lifestyle saat ini juga sedang banyak diperbincangkan oleh masyarakat luas baik di dalam negeri maupun di luar negeri. Hal ini bisa dilihat dari dominasi media elektronik, berita online hingga acara seminar yang mengusung tema halal lifestyle. Tidak heran jika halal lifestyle sudah menjadi gaya hidup kekinian bagi umat Islam khususnya para kaula muda. Mulai dari wisata halal, kosmetik halal, obat-obatan halal, sampai dengan gaya berbusana yang halal. Meningkatnya pengaruh media sosial mempengaruhi market share industri halal (Adinugraha \& Sartika, 2019) 


\section{METODOLOGI PENELITIAN}

Metode penelitian menggunakan metode deskriptif dengan perpaduan pendekatan kualitatif dan kuantitatif. Jenis data yang digunakan dalam penelitian ini adalah data kuantitatif sebagai proses analisis dan data kualitatif yang bersifat induktif dalam arti cara menerangkannya dari data ke arah teori. Pendekatan deskriptif-eksploratif digunakan untuk menggambarkan hasil uji pengaruh variabel kualitas produk, nilai produk dan gaya hidup dalam memilih produk bersertifikat halal. Data sekunder juga digunakan yaitu dengan dilakukannya studi pustaka dengan penelusuran informasi melalui buku, artikel, jurnal, majalah, internet, dan sumber lainnya. Populasi yang dijadikan sebagai objek penelitian adalah generasi milenial dengan kriteria sampel yaitu generasi berusia di bawah 30 tahun dan tinggal di wilayah DKI Jakarta menggunakan teknik pengambilan Simple Random Sampling. Besarnya sampel sebanyak 232 responden menggunakan kuisioner skala liker 5 .

\section{HASIL PENELITIAN}

Sampel penelitian adalah generai milenial di wilayah DKI Jakarta. Pengumpulan data dilakukan selama 2 (dua) bulan pada bulan Mei sampai juni 2021. Data survei kuisioner dibagikan secara online melalui google form kepada 232 responden. Peneliti mendapatkan 232 kuesioner responden yang akan diolah.

Tabel 2. Deskripsi Responden

\begin{tabular}{|c|l|c|c|}
\hline \multirow{2}{*}{ Kategori } & \multicolumn{1}{|c|}{ Keterangan } & $\begin{array}{c}\text { Jumlah } \\
\text { Responden }\end{array}$ & Persen \\
\hline \multirow{3}{*}{ Jenis Kelamin } & Laki-laki & 64 & $29,3 \%$ \\
\cline { 2 - 4 } & Perempuan & 164 & $70,7 \%$ \\
\hline \multirow{5}{*}{ Usia } & 20-30 tahun & 223 & $96,1 \%$ \\
\cline { 2 - 4 } & 30-40 tahun & 9 & $3,9 \%$ \\
\hline \multirow{5}{*}{ Jenis Pekerjaan } & Pelajar/Mahasiswa & 183 & $78,4 \%$ \\
\cline { 2 - 4 } & PNS & 1 & $0,4 \%$ \\
\cline { 2 - 4 } & Pegawai Swasta & 29 & $12,9 \%$ \\
\cline { 2 - 4 } & Wirausaha & 11 & $4,3 \%$ \\
\cline { 2 - 4 } & Lainnya & 9 & $3,6 \%$ \\
\hline
\end{tabular}

Sumber: Data diolah (2021)

Hasil Tabel 2 menunjukkan sebanyak 232 responden mayoritas penelitian berjenis kelamin perempuan, berusia 20-30 tahun, dan jenis pekerjaan sebagai pelajar atau mahasiswa.

\section{Analisa Data}

Tabel 3. Hasil Pengujian Validitas Persepsi Kualitas Produk

\begin{tabular}{|c|c|c|c|}
\hline $\begin{array}{c}\text { Item } \\
\text { Pernyataan }\end{array}$ & r hitung & r Tabel & Keterangan \\
\hline X1.1 & 0,793 & 0,138 & Valid \\
\hline
\end{tabular}




\begin{tabular}{|c|c|c|}
\hline $\mathrm{X} 1.2$ & 0,812 & 0,138 \\
\hline $\mathrm{X} 1.3$ & 0,813 & 0,138 \\
\hline $\mathrm{X} 1.4$ & 0,759 & 0,138 \\
\hline $\mathrm{X} 1.5$ & 0,661 & 0,138 \\
\hline $\mathrm{X} 1.6$ & 0,750 & 0,138 \\
\hline $\mathrm{X} 1.7$ & 0,835 & 0,138 \\
\hline $\mathrm{X} 1.8$ & 0,840 & 0,138 \\
\hline
\end{tabular}

Sumber: Hasil Output SPSS (2021)

Tabel 4. Hasil Pengujian Validitas Persepsi Nilai Produk

\begin{tabular}{|c|c|c|c|}
\hline Item & R hitung & R Tabel & \multirow{2}{*}{ Keterangan } \\
\hline X2.1 & 0,783 & 0,138 & \\
\hline X2.2 & 0,735 & 0,138 & \multirow{2}{*}{ Valid } \\
\hline X2.3 & 0,690 & 0,138 & \multirow{2}{*}{} \\
\hline X2.4 & 0,701 & 0,138 & \\
\hline X2.5 & 0,697 & 0,138 & \\
\hline X2.6 & 0,780 & 0,138 & \\
\hline X2.7 & 0,785 & 0,138 & \\
\hline X2.8 & 0,784 & 0,138 & \\
\hline
\end{tabular}

Sumber: Hasil Output SPSS (2021)

Tabel 5. Hasil Pengujian Validitas Gaya Hidup

\begin{tabular}{|c|c|c|c|}
\hline Item & R hitung & R Tabel & \multirow{2}{*}{ Keterangan } \\
\hline X3.1 & 0,889 & 0,138 & \multirow{2}{*}{ Valid } \\
\cline { 1 - 2 } X3.2 & 0,735 & 0,138 & \multirow{2}{*}{} \\
\hline X3.3 & 0,886 & 0,138 & \\
\hline X3.4 & 0,874 & 0,138 & \\
\hline X3.5 & 0,840 & 0,138 & \\
\hline X3.6 & 0,748 & 0,138 & \\
\hline
\end{tabular}

Sumber: Hasil Output SPSS (2021)

Tabel 6. Hasil Pengujian Validitas Minat Membeli Produk Halal

\begin{tabular}{|c|c|c|c|}
\hline Item & R hitung & R Tabel & Keterangan \\
\hline Y.1 & 0,772 & 0,138 & \\
\hline Y.2 & 0,778 & 0,138 & \multirow{2}{*}{ Valid } \\
\hline Y.3 & 0,729 & 0,138 & \\
\hline Y.4 & 0,791 & 0,138 & \\
\hline Y.5 & 0,803 & 0,138 & \\
\hline Y.6 & 0,831 & 0,138 & \\
\hline
\end{tabular}

Sumber: Hasil Output SPSS (2021) 
Berdasarkan tabel diatas menyatakan bahwa seluruh item pertanyaan memiliki nilai $r$ hitung yang lebih besar dari pada nilai $r$ tabel $(0,138)$, dengan demikian dapat disimpulkan bahwa seluruh item pertanyaan indikator pada variabel minat membeli produk halal dapat dinyatakan valid dan dapat dipergunakan untuk mengukur variabel keputusan pembelian konsumen muslim pada pengujian berikutnya.

Tabel 7. Hasil Uji Reabilitas

\begin{tabular}{|l|c|c|}
\hline \multicolumn{1}{|c|}{ Variabel } & Cronbarch's Alpha & N of Items \\
\hline Kualiats Produk & 0,909 & 8 \\
\hline Nilai Produk & 0,884 & 8 \\
\hline Gaya Hidup & 0,900 & 6 \\
\hline $\begin{array}{l}\text { Minat Membeli } \\
\text { Produk Halal }\end{array}$ & 0,863 & 6 \\
\hline
\end{tabular}

Sumber: Hasil Output SPSS (2021)

Berdasarkan Tabel 7 diatas menunjukkan bahwa pada instrument yang mengukur variabel-variabel: kualitas produk memiliki nilai Alpha Cronbach sebesar 0,909, variabel nilai produk memiliki nilai Alpha Cronbach sebesar 0,884, kemudian variabel gaya hidup memiliki nilai Alpha Cronbach sebesar 0,900 dan variabel keputusan pembelian produk halal memiliki nilai Alpha Cronbach sebesar 0,863. Berdasarkan hasil penelitian instrument yang digunakan untuk mengukur variabel-vkualiats produk, nilai produk, gaya hidup dan minat membeli produk halal dapat dinyatakan reliabel karena telah melebihi batas minimum tingkat reliabilitas yakni 0,60 .

Tabel 8. Hasil Uji Normalitas

One-Sample Kolmogorov-Smirnov Test

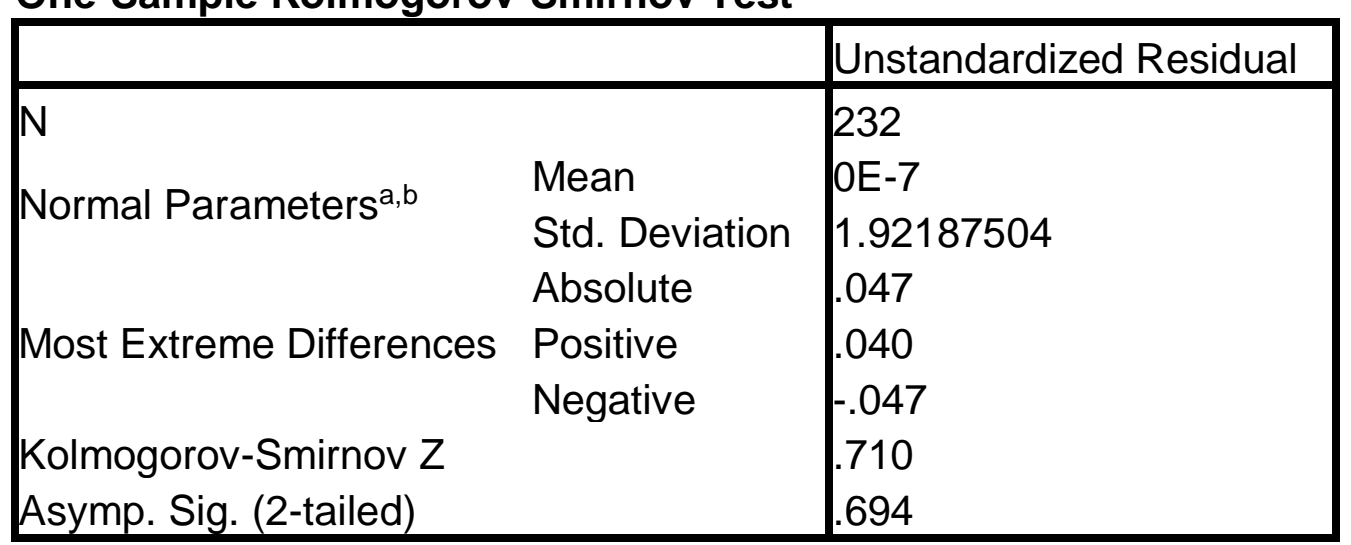

a. Test distribution is Normal.

b. Calculated from data.

Berdasarkan uji normalitas data dengan menggunakan Test Normality KolmogrovSmirnov data tabel pada model regresi diatas, dapat dilihat bahwa nilai probabilitasnya 0,694 yang berarti memiliki nilai lebih besar dari 0,05 sehingga dapat disimpulkan bahwa model regresi pada penelitian ini terdistribusi normal. 
Tabel 9. Hasil Uji Multikolinearitas

\begin{tabular}{|ll|l|l|}
\hline \multirow{2}{*}{ Model } & \multicolumn{2}{|l|}{ Collinearity Statistics } \\
\cline { 2 - 3 } & Tolerance & VIF \\
\hline (Constant) & & \\
1 Persepsi Kualitas Produk & 388 & 2.578 \\
Persepsi Nilai Produk & 231 & 4.320 \\
Gaya Hidup & 345 & 2.903 \\
\hline
\end{tabular}

Dari data tabel diatas dapat di atas menunjukan bahwa nilai VIF variabel persepsi kualitas produk (X1) adalah 2.578 dengan nilai tolerance value sebesar 0,388 . Untuk variabel persepsi nilai produk (X2) nilai VIF sebesar 4.320 dan nilai tolerance value sebesar 0,231 dan untuk variabel gaya hidup (X3) nilai VIF sebesar 2.903 dengan nilai tolerance value sebesar 0,345.Sehingga dapat disimpulkan bahwa model regresi dari variabel-variabel penelitian yaitu persepsi kualitas produk, persepsi nilai produk dan gaya hidup dalam penelitian ini tidak mengandung multikolenieritas karena memiliki nilai VIF kurang dari 10 dan nilai tolance value memiliki nilai lebih besar dari 0,1.

Tabel 10. Hasil Uji Heteroskedastisitas

\section{Coefficients $^{\mathrm{a}}$}

\begin{tabular}{|c|c|c|c|c|c|}
\hline \multirow[t]{2}{*}{ Model } & \multicolumn{2}{|c|}{$\begin{array}{l}\text { Unstandardized } \\
\text { Coefficients }\end{array}$} & $\begin{array}{l}\text { Standardized } \\
\text { Coefficients }\end{array}$ & \multirow[t]{2}{*}{ t } & \multirow[t]{2}{*}{ ig. } \\
\hline & $B$ & Std. Error & Beta & & \\
\hline (Constant) & .005 & .002 & & 2.149 & .033 \\
\hline X1_2 & .014 & .022 & .064 & .616 & .539 \\
\hline X2_2 & .013 & .029 & .058 & .443 & 658 \\
\hline X3_2 & $-5.361 \mathrm{E}-006$ & .000 & -.364 & -3.203 & .002 \\
\hline
\end{tabular}

a. Dependent Variable: ABS2

Berdasarkan Tabel 10 di atas menunjukkan bahawa variabel persepsi kualitas produk dan persepsi nilai produk memiliki tingkat signifikansi > 0,05 oleh karena itu dapat disimpulkan bahwa model regresi tidak terjadi masalah heterokedastisitas. Sedangkan variabel gaya hidup memiliki tingkat signifikansi $<0,05$ maka dapat disimpulkan bahwa model regresi pada variabel ini terjadi masalah heterokedastisitas.

Tabel 11. Hasil Uji Analisis Regresi Berganda

\section{Coefficients $^{\mathrm{a}}$}

\begin{tabular}{|l|l|l|l|l|}
\hline Model & $\begin{array}{l}\text { Unstandardized } \\
\text { Coefficients }\end{array}$ & $\begin{array}{l}\text { Standardized } \\
\text { Coefficients }\end{array}$ & Sig. \\
\cline { 1 - 4 } & Std. Error & Beta & \\
\hline
\end{tabular}




\begin{tabular}{|l|l|l|l|l|l|}
\hline (Constant) & 3.652 & .956 & & 3.821 & .000 \\
Persepsi Kualitas & .178 & .038 & .271 & 4.737 & .000 \\
Produk & & & & & \\
$\begin{array}{l}\text { Persepsi Nilai } \\
\text { Produk } \\
\text { Gaya Hidup }\end{array}$ & .5634 & .057 & .070 & .951 & .343 \\
\hline
\end{tabular}

a. Dependent Variable: Minat Membeli Produk Halal

Dari hasil analisis data Tabel 11 didapatkan persamaan regresi berganda sebagai berikut: $Y=3,652+0,178+0,054+0,563$

Dapat disimpulkan dari persamaan regresi diatas yaitu :

Nilai konstanta adalah sebesar 3,652 berarti jika tidak terjadi perubahan variabel variabel persepsi kualitas produk, persepsi nilai produk dan gaya hidup (nilai X1, X2 dan X3 adalah 0) maka nilai konsisten variabel keputusan pembelian konsumen muslim sebesar 3,652. Nilai koefisienxregresi X1 sebesar 0,178 yang menunjukan bahwa variabel persepsi kualitas produk (X1) mempunyai pengaruh yang positif terhadap minat membeli produk halal (Y), yang berarti setiapxpenambahan $1 \%$ nilai persepsi kualitas produk (X1), maka akan mempengaruhi minat membeli produk halal sebesarx 0,178. Nilai koefisienxregresi X2 sebesar 0,054 yang menunjukan bahwa variabel persepsi nilai produk (X2) mempunyai pengaruh yang positif terhadap minat membeli produk halal (Y), yang berarti setiapxpenambahan $1 \%$ nilai persepsi nilai produk (X2), maka akan mempengaruhi minat membeli produk halal sebesarx 0,054. Dan nilai koefisienxregresi X3 sebesar 0,563 yang menunjukan bahwa variabel gaya hidup (X3) mempunyai pengaruh yang positif terhadap minat membeli produk halal (Y), yang berarti setiapxpenambahan $1 \%$ nilai gaya hidup (X3), maka akan mempengaruhi minat membeli produk halal sebesarx0,563.

\section{Tabel 12. Hasil Uji Determinasi}

\section{Model Summary}

\begin{tabular}{|l|l|l|l|l|}
\hline Model & $R$ & R Square & $\begin{array}{l}\text { Adjusted R } \\
\text { Square }\end{array}$ & $\begin{array}{l}\text { Std. Error of the } \\
\text { Estimate }\end{array}$ \\
\hline 1 & $843^{\mathrm{a}}$ & 711 & .707 & 1.93448 \\
\hline
\end{tabular}

a. Predictors: (Constant), Gaya Hidup, Persepsi Kualitas Produk ,

Persepsi Nilai Produk

Berdasarkan Tabel 12 diatas dapat dilihat bahwa hasil uji koefisien determinasi tersebut memberikan hasil nilai R2 sebesar 0,711. Dengan demikian nilai tersebut mengartikan bahwa 71,1\% variabel Turnover Intention (Y) dipengaruhi oleh variabel persepsi kualitas produk (X1), persepsi nilai produk (X2) dan gaya hidup (X3) yang diteliti dalam 
penelitian ini, sementara sebesar $28,9 \%$ dipengaruhi oleh faktor variabel lain yang tidak diteliti dalam penelitian ini.

Tabel 13. Hasil Uji t

Coefficients $^{a}$

\begin{tabular}{|c|c|c|c|c|c|c|}
\hline \multirow[t]{2}{*}{ Mod } & & \multicolumn{2}{|c|}{ Unstandardized Coefficients } & \multirow{2}{*}{\begin{tabular}{|l} 
Standardized \\
Coefficients \\
Beta
\end{tabular}} & t & \multirow[t]{2}{*}{ Sig. } \\
\hline & & $B$ & Std. Error & & & \\
\hline \multirow{4}{*}{1} & (Constant) & 3.652 & .956 & & 3.821 & .000 \\
\hline & Persepsi Kualitas Produk & 178 & .038 & .271 & 4.737 & .000 \\
\hline & Persepsi Nilai Produk & .054 & .057 & .070 & .951 & 343 \\
\hline & Gaya Hidup & .563 & .059 & .578 & 9.532 & .000 \\
\hline
\end{tabular}

a. Dependent Variable: Minat Membeli Produk Halal

Berdasarkan pada pengujian Tabel 13 dapat dijelaskan sebagai berikut:

1. Variabel persepsi kualitas produk memiliki pengaruh secara positif dan signifikan terhadap minat membeli produk halal generasi milenial di Jakarta. Hal ini terlihat dari hasil signifikan persepsi kualitas produk (X1) $0,000<0,05$.

2. Variabel persepsi nilai produk tidak memiliki pengaruh secara positif dan signifikan terhadap minat membeli produk halal generasi milenial di Jakarta. Hal ini terlihat dari hasil signifikan persepsi kualitas produk (X2) 0,343>0,05

3. Variabel gaya hidup memiliki pengaruh secara positif dan signifikan terhadap minat membeli produk halal generasi milenial di Jakarta. Hal ini terlihat dari hasil signifikan persepsi kualitas produk (X1) $0,000<0,05$

ANOVA $^{\mathrm{a}}$

\section{Tabel 14. Hasil Uji F}

\begin{tabular}{|ll|l|l|l|l|l|}
\hline Model & & Sum of Squares & df & Mean Square & F & Sig. \\
\hline \multirow{3}{*}{1} & Regression & 2100.622 & 3 & 700.207 & 187.111 & $.000^{\mathrm{b}}$ \\
& Residual & 853.222 & 228 & 3.742 & & \\
& Total & 2953.845 & 231 & & & \\
\hline
\end{tabular}

a. Dependent Variable: Minat Membeli Produk Halal

b. Predictors: (Constant), Gaya Hidup, Persepsi Kualitas Produk, Persepsi Nilai Produk

Berdasarkan pada pengujian Tabel 14 diatas dapat dilihat bahwa Fhitung sebesar 187,111 dengan nilai Ftabel adalah 2,64, sehingga nilai Fhitung lebih besar dar Ftabel atau 187,111 2,64 dan tingkat signifikan 0,000 < 0,05 maka H0 ditolak dan Ha diterima sehingga dapat diambil kesimpulan secara simultan variabel persepsi kualitas produk (X1), persepsi nilai produk (X2) dan gaya hidup (X3) secara bersamaan mempunyai pengaruh signifikan terhadap minat membeli produk halal generasi milenial di Jakarta

\section{Pembahasan}

\section{Pengaruh persepsi kualitas produk terhadap minat membeli produk halal}


Hasil penelitian menunjukkan persepsi kualitas produk memiliki pengaruh positif signifikan terhadap minat membeli produk halal. Hasil penelitian mendukung Ismunandar et.al (2021) dan Setiawan (2020) dapat disimpulkan dalam penelitian ini bahwa konsumen mempersepsikan produk-produk halal mempunyai kualitas produk yang baik sehingga mendorong minat generasi milenia untuk membeli produk halal.

2. Pengaruh persepsi nilai produk terhadap minat membeli produk halal

Hasil pengujian diketahui bahwa persepsi nilai produk tidak memiliki pengaruh positif signifikan terhadap minat membeli produk halal. Hasil penelitian tidak mendukung hasil penelitian Chang et.al (2008) menemukan bahwa persepsi nilai memiliki dampak positif signifikan pada minat pembelian. Semakin besar persepsi yang diterima atau dirasakan konsumen maka akan berdampak pada minat pembelian yang tinggi. Sebaliknya jika persepsi nilai yang didapatkan konsumen lebih kecil maka minat membeli konsumen rendah. Dan tidak mendukung hasil penelitian (Nurhasanah et.al (2017) Nilai yang dipersepsikan adalah bahwa makanan halal merupakan favorit pembelian, harga makanan sesuai dengan nilainya dan memiliki kualitasyang sesuai dengan nilainya.

3. Pengaruh persepsi gaya hidup terhadap minat membeli produk halal

Hasil penelitian mendukung Rumbiati dan Heriyana (2020) dan Putra (2019). Membuktikan bahwa terdapat pengaruh positif signifikan antara variabel gaya hidup terhadap minat. Hasil penelitian ini juga selaras dengan pernyataan dari Kotler dan Amstrong (2008) yaitu terdapat dua faktor yang mempengaruhi gaya hidup seseorang: faktor eksternal dan faktor internal yang berasal dari dalam individu salah satunya adalah secara langsung perilaku seseorang dipengaruhi dimana sikap dapat dipahami sebagai cara seseorang dalam memberikan tanggapan terhadap suatu hal disesuaikan dengan pemikiran dan kondisi jiwa berdasarkan pengalaman.

4. Pengaruh persepsi kualitas produk, nilai produk dan gaya hidup terhadap minat membeli produk halal

Hasil pengujian menunjukkan kualitas produk, nilai produk dan gaya hidup secara bersama-sama mempengaruhi minat membeli produk halal. Hasil mendukung penelitian Putra (2019) menjelaskan pengaruh lifestyle dan perceived quality bersama-sama memiliki pengaruh positif dan kuat terhadap minat beli.

\section{KESIMPULAN}

Berdasarkan hasil analisis dan pembahasan penelitian yang telah diuraikan sebelumnya mengenai Persepsi Generasi Milenial Dalam Memilih Produk Bersertifikat Halal di Jakarta serta pengujian yang telah dilakukan maka dapat disimpulkan bahwa:

1. Persepsi kualitas produk memiliki pengaruh secara positif dan signifikan terhadap minat membeli produk halal generasi milenial di Jakarta

2. Persepsi nilai produk tidak memiliki pengaruh secara positif dan signifikan terhadap minat membeli produk halal generasi milenial di Jakarta

3. Gaya hidup memiliki pengaruh secara positif dan signifikan terhadap minat membeli produk halal generasi milenial di Jakarta

4. Variabel persepsi kualitas produk, persepsi nilai produk dan gaya hidup secara bersamaan mempunyai pengaruh signifikan terhadap minat membeli produk halal generasi milenial di Jakarta 


\section{UCAPAN TERIMA KASIH}

Terima kasih kepada Universitas Pembangunan Nasional Veteran Jakarta, Fakultas Ekonomi dan Bisnis, Rekan Dosen, para mahasiswa dan keluarga atas dukungan yang diberikan kepada penulis dalam menyelesaikan penelitian ini. Semoga penelitian ini dapat bermanfaat untuk masyarakat luas khususnya dalam hal meningkatkan minat pembelian produk halal. Tentunya karya ilmiah ini terdapat kelemahan yang perlu disempurnakan untuk penelitian selanjutnya.

\section{DAFTAR PUSTAKA}

Adinugraha, H. H., \& Sartika, M. (2019). Halal Lifestyle Di Indonesia. An-Nisbah: Jurnal Ekonomi Syariah, 5(2), 57-81. https://doi.org/10.21274/an.2019.5.2.layout

ArismanUtama, I., \& Jaya, R. K. (2017). Survei “Confidence Level” Konsumen Terhadap Produk Halal di Jakarta. Repository.Uai.Ac.Id.

Chairani, D. (2021). Pentingnya Sertifikasi Halal untuk Sebuah Produk. Tribun Bisnis.

Chang, Chen, dan S. W. Chen. (2008) .'The Impact of Online Store Environment Cues On Purchase Intentions: Trust and Perceived Risk as a Mediator", Online Information Review, 32(6), pp. 818-841.

Darmadi Durianto, S. (2001). Strategi Menaklukkan Pasar Melalui Riset Ekuitas dan Perilaku Merek. Gramedia Pustaka Utama.

Dewi Samad, T. F. (2019). Pengaruh Persepsi Label Halal Terhadap Preferensi Konsumen pada Restoran Pizza Hut dan KFC di Yogyakarta. FALAH: Jurnal Ekonomi Syariah, 4(1), 1. https://doi.org/10.22219/jes.v4i1.7960

Dr. Hj. Nuraeni Kadir, S.E., M. S., Munir, A. R., Dr. Hj. Jumidah Maming, S.E., M. S., \& Dr. Fauziah Umar, S.E., M. . (2020). MODEL PENGEMBANGAN USAHA PENSUTERAAN.Surabaya: CV Jakad Publising Surabaya.

Fahmi, S. (2017). Halal labeling effect on muslim consumers attitude and behavior. 131(Icoi), 56-62. https://doi.org/10.2991/icoi-17.2017.26

Farhan, A. (2019). Pelaksanaan Sertifikasi Halal Lppom Mui Terhadap Produk Usaha Mikro, Kecil Dan Menengah (Umkm) (Studi Lppom Mui Provinsi Bengkulu). Manhaj: Jurnal Penelitian Dan Pengabdian Masyarakat, 3(1), 1. https://doi.org/10.29300/mjppm.v3i1.2340

Harjati, L., \& Sabu, O. (2014). Produk Terhadap Keputusan Pembelian The Body Shop. E-Journal WIDYA Ekonomika, 1(November). https://doi.org/ISSN 2338-7807

HumasKemenkop, K. K. dan U. (2020). PELAKU UMKM AKAN DAPATKAN SERTIFIKAT HALAL GRATIS. Depkop.Go.Id. 
Ismunandar., Muhajirin., \& Intisari Haryanti, (2021). Pengaruh Labelisasi Halal Dan Kualitas Produk Terhadap Keputusan Pembelian Produk UMKM Di Kota Bima. Jurnal Inovasi Penelitian, 2(1), https://doi.org/10.47492/jip.v2i1

Kirana, D., W., Widiyanto, I., \& Manajemen, J. (2015). Sikap Masyarakat Muslim Terhadap Produk Makanan Non-Halal Di Kota Semarang. Diponegoro Journal of Management, 4(2), 1-12.

Kompasiana. (2020). Gaya Hidup Konsumtif Generasi Milenial. Kompasiana.

Kotler, Philip dan Amstrong. 2008. Prinsip-Prinsip Pemasaran. Edisi 12.Jilid 1. Alih Bahasa Bob Sabran. Jakarta: Erlangga

Pramelani, P. (2020). Faktor Ketertarikan Minuman Kopi Kekinian Terhadap Minat Beli Konsumen Kalangan Muda. Managament Insight: Jurnal Ilmiah Manajemen, 15(1), 121-129. https://doi.org/10.33369/insight.15.1.121-129

Putra, AHPM., (2019). Pengaruh Percieved Quality, Harga Dan Lifestyle Terhadap Minat Beli Produk Oldman.Co. Jurnal Mitra Manajemen (JMM Online), 3(11), 10381054. https://doi.org/10.52160/ejmm.v3i11

Qomaro, G. W., \& Mawaddah, I. (2019). Product Liability dan Perlindungan

Konsumen Terhadap Produk Berlabel Halal Palsu. Jurnal Pamator: Jurnal Ilmiah , 12(2), $78-83$.

Nurhasanah, S., Munandar, JM., \& Syamsun M. (2017). Faktor-Faktor yang Mempengaruhi Minat Beli Produk Makanan Olahan Halal pada Konsumen. Jurnal Manajemen dan Organisasi. 250-260. https://doi.org/10.29244/jmo.v8i3.22473

Rangkuti, F. (2002). Measuring Customer Satisfaction. Jakarta: PT. Gramedia Pustaka Utama.

Rifyal Dahlawy Chalil. (2020). Brand, Islamic Branding, dan Rebranding: Peran Strategi Merek Dalam Menciptakan Daya Saing Industri Dan Bisnis Global. Rajawali Pers.

Rumbiati \& Heriyana. (2020). Pengaruh Gaya Hidup dan Kemudahan Terhadap Minat Beli Mahasiswa dalam Berbelanja Online. Jurnal Aplikasi Manajemen dan Bisnis. 1(1), 57-65. https://doi.org/10.5281/zenodo.4697944

Safira, M. E., Roihanah, R., Khasanah, U., \& Mufidah, L. (2014). MASYARAKAT MILENIAL MELEK HUKUM AKSELERASI PRODUK HALAL BERJAYA DI PENTAS DUNIA. 1(2), 243-254.

SAID, R., \& SEKALI, A. S. K. (2019). Agriprimatech NIAT BELI PRODUK HALAL PADA KONSUMEN NON-MUSLIM GENERASI A griprimatech. 3(1), 1-8.

Setiadi, N. J. (2019). Perilaku Konsumen: Perspektif Kontemporer pada Motif, Tujuan, dan Keinginan Konsumen Edisi Ketiga (Vol. 3). Prenada Media. 
Setiawan, R. (2020). Pengaruh Kualitas Produk dan Promosi Terhadap Minat Beli Yang Berdampak Pada Keputusan Pembelian Pada Pelanggan Aprilia Bakery. Jurnal Pemasaran Kompetitif. 3(3). http://dx.doi.org/10.32493/jpkpk.v3i3.5141

Setyaningsih, E. D., \& Marwansyah, S. (2019). The Effect of Halal Certification and Halal Awareness through Interest in Decisions on Buying Halal Food Products. Syi ar Iqtishadi : Journal of Islamic Economics, Finance and Banking, 3(1), 65. https://doi.org/10.35448/jiec.v3i1.5515

Soegoto, A. (2013). Persepsi Nilai Dan Kepercayaan Terhadap Kepuasan Dan Dampaknya Terhadap Loyalitas Konsumen. Jurnal Riset Ekonomi, Manajemen, Bisnis Dan Akuntansi, 1(3), 1271-1283. https://doi.org/10.35794/emba.v1i3.2548

Sumarwan, U. (2011). Manajemen ... Perilaku Konsumen Teori Dan Penerapannya Dalam. Pemasaran. Jakarta: PT Ghalia Indonesia.

Ulya, F. N. (2020). Lewati Jakarta, Bekasi Jadi Kota dengan Biaya Konsumsi Tertinggi di Indonesia. Kompas.Com.

Warto, W., \& Samsuri, S. (2020). Sertifikasi Halal dan Implikasinya Bagi Bisnis Produk Halal di Indonesia. Al Maal: Journal of Islamic Economics and Banking, 2(1), 98. https://doi.org/10.31000/almaal.v2i1.2803

Winata, N. D., Puspitasari, I., \& Saputra, M. H. (2016). Persepsi Tentang Label Halal terhadap Keputusan Pembelian. (3), 1-11.

Wulan Ayodya. (2008). Usaha Aneka Katering Laris. PT Elex Media Komputindo (Gramedia Group).

Yulita Amalia, R., \& Fauziah, S. (2019). Perilaku Konsumen Milenial Muslim Pada Resto Bersertifikat Halal Di Indonesia: Implementasi Teori Perilaku Terencana Ajzen. JEBA (Journal of Economics and Business Aseanomics), 3(2), 200-218. https://doi.org/10.33476/jeba.v3i2.960

Yuliyanto, J. (2020). Menimbang (Kembali) Sertifikasi Halal. Detik.Com.

Yuriansyah, A. L. (2013). Persepsi Tentang Kualitas Pelayanan, Nilai Produk Dan Fasilitas Terhadap Kepuasan Pelanggan. Management Analysis Journal, 2(1). https://doi.org/10.15294/maj.v2i1.1408

Zulfi, J., Kusnandar, K., \& Qonita, R. A. (2018). Analisis Preferensi Konsumen Terhadap Pembelian Kopi Instan White Coffee Di Kecamatan Kebumen Kabupaten Kebumen. SEPA: Jurnal Sosial Ekonomi Pertanian Dan Agribisnis, 14(2), 159. https://doi.org/10.20961/sepa.v14i2.25008

Zulham, S.Hi., M. H. (2013). Hukum Perlindungan Konsumen. 